\title{
Acido, ergo sum: Holger Hydén - the neuroscientist in Cortázar's Hopscotch
}

\author{
Acido, ergo sum: Holger Hydén - o neurocientista em O Jogo da Amarelinha, de Cortázar \\ Guillermo Delgado, Bruno Estañol
}

\begin{abstract}
The fictional Italian author Morelli is throughout the novel "Hopscotch" (1963) Julio Cortázar's alter ego. This character proposes an unoriginal literary hypothesis in chapter 62. There is an allusion to a particular Swedish that 'is working on a chemical theory of thought.' The Swedish neuroscientist under analysis is Holger Hydén (1917-2000), by then professor and chairman of the Department of Histology at the University of Göteborg. Hydén, who was the first to work in neurobiological micromethods, is mentioned by Morelli due to his participation in a symposium held at the end of January 1961, in San Francisco. His pioneering work will never be completely forgotten, because Hydén's neuroscientific legacy lives and will live in Cortázar's "Hopscotch".
\end{abstract}

Key words: neurosciences, biography, Sweden, medicine in literature, Argentina.

\section{RESUMO}

O autor italiano de ficção Morelli atua, no romance "Jogo da Amarelinha" (1963), como o alter ego de Julio Cortázar. Este personagem propõe uma hipótese literária sem originalidade no capítulo 62. Há uma alusão a um sueco em particular que "está trabalhando em uma teoria química do pensamento". O neurocientista sueco em questão é Holger Hydén (1917-2000), então professor e diretor do Departamento de Histologia da Universidade de Gotemburgo. Hydén, que foi o primeiro no uso de métodos para a microdissecção de neurônios individuais, é mencionado por Morelli devido a sua participação em um simpósio realizado em São Francisco, no final de janeiro de 1961. Seu trabalho pioneiro nunca será esquecido completamente porque seu legado neurocientífico vive e vai viver em “Jogo da Amarelinha", de Cortázar.

Palavras-Chave: neurociências, biografia, Suécia, medicina na literatura, Argentina.

\section{Cette hypothèse paraît délirante}

Pauwels and Bergier, Le Matin des magiciens ${ }^{1}$

As stated in the Table of Instructions, Julio Cortázar's Hopscotch (1963) is several books, but above all it is two ones. The rationale of the second is explained throughout the work written by Morelli, a fictional Italian author-philosopher. Moreover, the dispensable chapters are crucial in this latter book for understanding Morelli's account. This cruciality is illustrated in chapter 62 , which encompass a Morelli's note or Morelliana. While this is not in Hopscotch's manuscript, it is not idle to speculate about its origin. Similar to the other dispensable chapters in Hopscotch, it was supposedly written in parallel with the chapters of the first book. Perhaps Cortázar wrote it while sitting in a coffee shop, upon reading the newspaper headlines over his breakfast ${ }^{1}$.
Morelli is presented as the literary theorist fed up with the psychological causality of narrative. He seeks an impersonal drama: without Oedipus, without Rastignac, without Phaedra; in which certain individuals unintentionally influence the depth chemistry of the other and vice versa. There is an allusion in his unoriginal literary proposal to a particular Swedish who "is working on a chemical theory of thought." The fictional author-philosopher's interest in neuroscience is striking but not unexpected, inasmuch as he usually embraced enthusiastically the latest working hypotheses of physics and biology ${ }^{1}$.

Also in such chapter, the Hopscotch's author includes a footnote, an excerpt from the French magazine L'Express, which discusses the address delivered in San Francisco by Swedish neuroscientist Holger Hydén (1917-2000), as seen in Figure, of the University of Göteborg, about his theories on the chemical nature of mental processes. His highly technical

Laboratory of Clinical Neurophysiology, Department of Neurology and Psychiatry, National Institute of Medical Sciences and Nutrition Salvador Zubirán, Mexico City, Mexico.

Correspondence: Guillermo Delgado, Laboratory of Clinical Neurophysiology, Department of Neurology and Psychiatry, National Institute of Medical Sciences and Nutrition Salvador Zubirán; Vasco de Quiroga 15; 14000 Tlalpan - México; E-mails: grdelgadog@gmail.com / guillermo.delgadogr@uanl.edu.mx Conflict of interest: There is no conflict of interest to declare.

Received 30 October 2012; Received in final form 16 November 2012; Accepted 23 November 2012. 
presentation is reported at times in a sensationalistic manner in this popular science piece ${ }^{1,2}$.

Hydén pioneered neurobiological micromethods ${ }^{3,4}$. At the time of the now-famed symposium, he was the Professor and Chairman of the Department of Histology, positions he retained until his retirement in $1983^{2,5}$. Hydén was born in Stockholm in 1917. At the age of 20 he entered the Karolinska Institutet as a medical student and received his $\mathrm{MD}$ in 1945. His PhD dissertation was entitled "Protein metabolism in the nerve cell during growth and function" 2 . Hydén developed methods for the microdissection of single neurons, and demonstrated that their content of ribonucleic acid (RNA) and proteins increased in response to stimuli and learning situations ${ }^{2-4}$. He had earned an international reputation already in the 1950s, and since this period he was a close friend of the author Arthur Koestler. He also served as Prorector of the University of Göteborg for two periods, Hydén in 2000 at the age of $83^{2,3}$.

The symposium in question, organized by the University of California San Francisco Medical Center and held at the end of January 1961, was officially devoted to the control of the mind ${ }^{5,6}$. Hydén presented his address "Biochemical Aspects of Brain Activity" and immediately made press headlines ${ }^{6,7}$ : The following is the fragment that caught media attention ${ }^{5,6}$.

"In considering the problem of mind control, one finds that these data give rise to the following question: would it be possible to change the fundamental of the emotion and the subjective experience of emotion-producing stimuli by inducing molecular changes in the biologically active substances of the brain? The RNA, in particular, is the main target for such speculation, since its molecular change may lead to a change in the protein being formed. A person may phrase the question in different words to modify the emphasis: do the experimental data presented here provide means to modify the mental state by specifically inducing chemical changes? Results pointing in that direction have been obtained; this work was carried out using a substance called tricyanoaminopropene (TRIAP)".

"The application of a substance changing the rate of production and composition of RNA and provoking enzyme alterations in the functional units of the central nervous system has both negative and positive aspects. There is evidence that TRIAP administration is followed by an increased suggestibility in men. Thus, a defined change of such a functionally important substance as the RNA in the brain could be used for conditioning. The author is not referring specifically to TRIAP, but to any substance inducing changes of biologically important molecules in the neurons and the glia and affecting the mental state in a negative direction. It is not difficult to imagine the possible uses to which a government in a police-controlled state could put this substance. On the other hand, a countermeasure against the effect of a substance such as TRIAP is not difficult to imagine either".

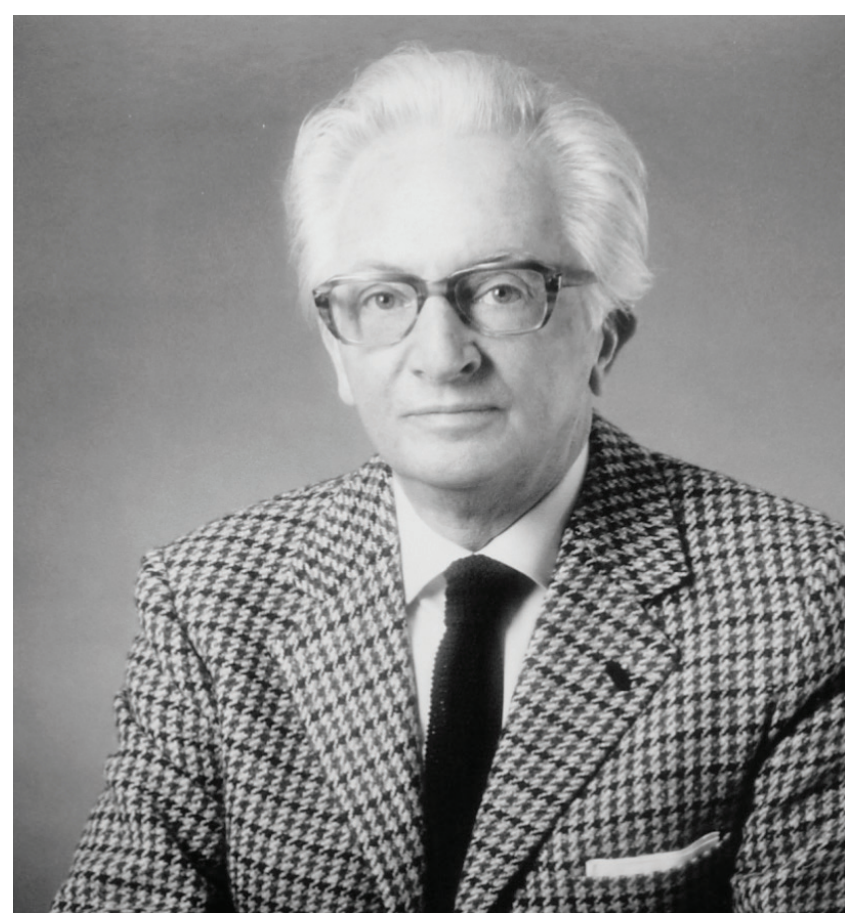

Figure. Holger Hydén. Photograph taken by Lennart Nilsson; reproduced with permission granted by professor Anders Hamberger (Department of Anatomy and Cell Biology, University of Göteborg).

Evidence cited by Hydén for the TRIAP-related increased suggestibility comes from one study by Gomirato et al. ${ }^{8}$. The Swedish neuroscientist is mentioned afresh in chapter 99 by Horacio Oliveira, Hopscotch's main character. Due to Hydén's work on RNA, Oliveira paraphrases Cervantes's well-known line and then does the same with Descartes, as follows: "Thinking is the result of the interaction of some acids whose name I do not wish to recall. Acido, ergo sum"1. Cortázar’s next novel, “62: A Model Kit” (1968), derives from Hopscotch's chapter 62 as a partial realization of Morelli's literary hypothesis ${ }^{9}$. Since we are not interested in studying analytically Morelli's tricks, is sufficient to state that he has been identified as Cortázar's alter ego ${ }^{1,9}$.

Hydén's pioneering work will never be completely forgotten, because his neuroscientific legacy lives and will live in Cortázar's Hopscotch: "The novel that interests us is not one that places characters in a situation, but rather one that puts the situation in the characters. By means of this the latter cease to be characters and become people," Morelli wrote it somewhere ${ }^{1,10}$.

\section{ACKNOWLEDGMENTS}

The authors would like to thank professors Anders Hamberger and Marco Piccolino for their generous assistance. See also Hopscotch's Chapter $60^{1}$. 


\section{References}

1. Cortázar J, Ortega J, Yurkievich S (eds). Rayuela. 2nd ed. Madrid: ALLCA XX; 1996.

2. Dahlström A, Hamberger A. Holger Hydén 1917-2000. Neurochem Res 2001;26:335-336.

3. Hertz L, Hansson E, Rönnbäck L. Signaling and gene expression in the neuron-glia unit during brain function and dysfunction: Holger Hydén in memoriam. Neurochem Int 2001;39:227-252.

4. Rose SP. Holger Hyden and the biochemistry of memory. Brain Res Bull 1999;50:443.
5. Farber SM, Wilson RHC. Man and civilization: control of the mind. New York: McGraw-Hill; 1961.

6. Koestler A. Bricks to Babel. London: Hutchinson; 1980

7. [no authors]. The chemistry of thought. Time, February 10, 1961.

8. Gomirato G, Ferro-Milone F, Martinelli G. Clinical and experimental observations on the effect of the preparation $U 9189$ (tricyanoamino-propene). Rass Studi Psichiatr 1961;50:341-352.

9. Bloom H. Julio Cortázar. New York: Chelsea House Publishers; 2005

10. Cortázar J. Hopscotch. Translated by Gregory Rabassa. New York: Pantheon Books; 1966. 